Rai, S.S., Prakasam, K.S., and Agrawal, N., 1999, Pn wave velocity and Moho geometry in north eastern India:

Proceedings of the Indian Academy of Sciences: Earth and Planetary Sciences, v. 108, p. 297-304.

Scholz, C.H., 2000, Evidence for a strong San Andreas fault: Geology, v. 28, p. 163-166.

Sonder, L.J., and England, P., 1986, Vertical averages of rheology of the continental lithosphere: relation to thin sheet parameters: Earth and Planetary Science Letters, v. 77 , p. 81-90.

Watts, A.B., Bodine, J.H., and Ribe, N., 1980, Observations of flexure and the geological evolution of the Pacific Ocean basin: Nature, v. 283, p. 532-537.

Wiens, D.A., and Stein, S., 1983, Age dependence of intraplate seismicity and implications for lithospheric evolution: Journal of Geophysical Research, v. 88, p. 6455-6468.

Withers, P., 2001, Gujarat aftershock epicenters and temporary station locations: www.ceri.memphis. edu/ withers/Gujarat/ (December 2001)

Yuan, X., Ni, J., Kind, R., Mechie, J., and Sandvol, E., 1997 Lithospheric and upper mantle structure of southern Tibet from a seismological passive source experiment, Journal of Geophysical Research, v. 102, p. 27,491-27,500.

Zhu, L., and Helmberger, D.V., 1996, Intermediate depth earthquakes beneath the India-Tibet collision: Geophysics Research Letters, v. 23, p. 435-438.

Manuscript received March 22, 2002, accepted July 4, 2002.

\section{Notice of Council Meeting}

Meetings of the GSA Council are open to Fellows, Members, and Associates of the Society, who may attend as observers, except during executive sessions. Only councilors and officers may speak to agenda items, except by invitation of the chair. Because of space and seating limitations, you will need to notify the Executive Director prior to the meeting if you plan to attend.

The next meeting of the Council will be at 1 p.m., Saturday, October 26, and at 1 p.m., Tuesday, October 29, at the GSA Annual Meeting in Denver.

DIALOGLE

\title{
Geology and Public Policy Committee Activities and Goals
}

Lou Gilpin, Chair, Geology and Public Policy Committee, Igilpin@gilpingeosciences.com

"In order to secure adequate funding for geological research and credibility and respect for our profession, we must learn to promote the value of our work."

—Rachel Sours-Page, 2000-2001 GSA-U.S

Geological Survey Congressional Science Fellow (GSA Today, January 2002).

This succinct and insightful quote from a former congressional fellow provides an appropriate mission statement for the Geology and Public Policy (G\&PP) Committee.

Our profession is diverse, yet it impacts people in their daily lives in many waysfrom a child's education of natural processes and the availability of clean water to preparation for natural hazards that may affect safety and livelihood of entire communities. GSA members contribute in all the fields of geology that ultimately benefit communities. My background is in applied engineering geology. I have experienced the responses from local officials and business people that view geological information as a research tool that adds color to the local natural history. Furthermore, they perceive this information to have little impact on planning and development guidelines that serve to protect human lives, property, and the environment.

The geological community can learn from our more service-oriented geotechnical and civil engineering partners who are continually reminding individuals, communities, and government agencies of the need to maintain and upgrade our infrastructure. For example, the American Society of Civil Engineers 2001 Report Card for America's Infrastructure is provided to Congress on an annual basis. The 2001 Report Card gave an overall grade of $\mathrm{D}+$ to the nation's infrastructure.

What would a Report Card of Natural Hazard Preparedness look like? GSA members as a group are certainly capable of producing such an assessment. The public perception of the need for the geological sciences is not as accurate as their perception of the need for engineering. Engineers design buildings and roads and build bridges; it is up to us to point out our con- tributions to the identification and management of natural hazards. Geologists regularly develop groundwater and mineral resources, assess vulnerability of structures and property to geologic hazards, and judge the appropriate scale of community development in areas subject to natural hazards. In addition, geologists have a special responsibility in the field of education to ensure dissemination of accurate and appropriate earth science information to students, communities, and policy makers.

As the new chair of the committee on which I have served since 1999, I hope to continue the numerous relationships and new projects that my predecessors (most recently, Geoff Feiss) have fostered. Such projects include:

- Actively servicing a G\&PP list server with congressional updates and announcements of policy decisions that affect the earth sciences community.

- Funding for a Public Policy Speakers Tour new in 2002-2003. This tour will provide a venue for public policy topics to be presented at Section meetings and at local universities. Information will be forthcoming in GSA Today.

- Developing several position statements (Need for Geological Mapping and Natural Hazards Assessment) that we plan to complete and publish in GSA Today for your comments.

We continue the Congressional Science Fellow program, in partnership with the USGS, with a new appointee for 2002-2003, Raphael Sagarin, who has been active in climatic and biological systems research on the West Coast. (See page 25 for more information on Sagarin.) This program has provided an extraordinary team of geologists who now have advanced their careers, and our profession, in the public light since their involvement in the program. My interaction with these exceptional individuals over the past three years has certainly been one of the highlights of serving on the G\&PP committee.

Most of all I look forward to discussing the policy issues with you, the membership, and to working with the committee and GSA to "market" the great value that geologists provide to communities across the nation and the world today. 